\title{
IMPACT OF TOURISM TO POVERTY IN TOURISM DESTINATION: PRO POOR TOURISM MANAGEMENT APPROACH
}

\author{
I Wayan Suardana, I Nyoman Sudiarta. \\ Udayana University \\ Suar_dana@yahoo.co.id, sudiarta.nyoman@yahoo.co.id
}

\begin{abstract}
This study aims to determine the typology of poverty, the causes of poverty and the impact of tourism on the poor, in the region Tulamben and Candidasa, Karangasem district. Research using purposive sampling method with a sample size 94 respondents. The data analysis using quantitative descriptive analysis. The research results are as follows. Typology of poverty of coastal communities, among others: age dominated 60 years and over, low education (graduated SD), the average income of 300,000 / month. Causes of poverty include natural factors, cultural factors, and the lack of poor people to work in the tourism sector. The impact of tourism on coastal communities on the one hand a positive impact on the opportunities opening new jobs like being a guest introductory diving, porter, and souvenir sellers.
\end{abstract}

Keywords: The impact of tourism, poverty, pro-poor tourism, management, tourism destination, approach.

\section{Introduction}

Ashley et al (2000) suggest tourism has several advantages for the economy that is pro-poor, because: (1) the customer comes to the destination, thus providing an opportunity to sell goods and services, such as souvenirs, (2) tourism provides an opportunity to diversify the local economy, in which tourism is developed. (3) tourism offer more job opportunities intentions. It supported the results of the World Tourism Organization (2015), which states tourism as an industry role in creating employment both directly and indirectly.

Ashley (2006) states Pro Poor Tourism (PPT) is the positive impact of tourism for the poor. PPT is not a product but an approach towards industry, where tourism is expected to increase community participation in various tourism sectors. PPT aimed to improve the community economy, increasing social benefits of tourism, and reduce the negative impacts of tourism.

Tourism management who care about poverty in line with the mandate of the Act that the tourism of the Republic of Indonesia in 2009, that aims to improve the tourism economy, society, employment and poverty (Undang Undang No 10 tahun 209) Several studies related to tourism and poverty in various parts of the world illustrates the importance of tourism for tourism 
practitioners, government and academia (Sudiarta et al, 2011).

Several studies describe their inconsistent results, the role of tourism in poverty alleviation. Some researchers suggest tourism has a role to alleviate poverty. However, other researchers said it was not convinced of the role of tourism in alleviating poverty. On the basis of the results of the study are not consistent, the role of tourism in alleviating poverty. So this study is expected to reduce the gap phenomena and produce research results that are consistent. This study concentrates on a concept developed by Asley and indicators used are relevant to the problems of poverty in Indonesia, especially in Bali.

This study aims to determine the typology of poverty, the causes of poverty and the impact of tourism on the poor, in the area of Tulamben and Candidasa in district of Karangasem. The research is expected to contribute to developing academic research model empirically based tourism and poverty. This study is also expected to be useful for the government and tourism by utilizing the tourism industry as a tool to alleviate poverty.

Provide a brief background to the topic, with some statistics or data to provide a background to the environment or situation. Explain why the study is needed from a research and/or practice perspective.

\section{Literature Review}

\section{Tourism versus Poverty}

Several research related tourism and poverty such as Leon (2007), which examined the impact of tourism on rural communities, especially in the coastal community of household poverty in the Dominican Republic. Researchers who also addressed the issue of poverty among Richins and Hull (2014: 292); Darma Putra and Pitana (2010); Suardana, (2004); Sudiarta, 2011); Madium (2010); conduct research in the tourism area of Nusa Dua. The finding of tresearch that happens hegemony ruling on the rights of local communities in tourism development.

Furthermore declared, the tourism industry makes local people become marginalized who were defeated by big businessmen. Given the limitations of society, such as communication skills in foreign languages, capital, network, and competence. This has resulted in the failure of local communities in participating in tourism as a form of community-based tourism.

\section{Pro -Poor Tourism Approach}

Although research on tourism and poverty has been done, however some researchers claim that the data regarding the amount of tourism's role in poverty alleviation is still limited (Damanik and Kusworo, 2005: 107). The emergence of the concept of pro-poor tourism, even translated as selling of poverty, as the tour visited pockets of poverty, as happened in the case of tour in Jakarta (Subagja, 2010: 1).

Elsewhere the tourism considered have been able to reduce poor society (Ashley and Roe, 2002), especially by empowering the people working in the tourism sector directly or indirectly. The same was happened in Namibia and Uganda (Ashly and Roe, 2002) the economic benefit is very important for improving the conservation of the area. Similar findings were also written by 
Leon (2007: 349-356) states that the tourism impacts on the livelihoods of people in the Dominican Republic.

Maximizing the impact of tourism on local communities should not be on a large scale. The study was conducted by Hill et al (2005), found the development the tourism based on nature and small scale in the province of Kwazulu-Natal, South Africa was able to overcome the economic crisis. Other research from the Mograbi and Rogeron (2007: 85-102) in the case of maritime tourism in South Africa Sodwana bay. The mechanism of control, decision making patterns conducted by the the head of operator groups equitably, can increase the income of the community significantly.

Moreover are found the real impact of poverty is the increased of labor especially dive operators (with 637 of the local community with $52 \%$ of local community, $47 \%$ from outside the region, and $28 \%$ from outside the area. Business dominant growing is a craft, lodging, as well as facilities for diving, and the production of firewood.

\section{Definition and Categories of Poverty}

including

The problem of poverty is a central issue in developing countries, Indonesia, especially after the crisis of 1998 Levitan 1980 (in Nawawi, 2009: 119) mentions poverty is the deficiencies of goods and services needed to achieve a reasonable standard of living. Lewis (in Usman, 2009) categorizes poverty based on three approaches, namely the cultural, situational approach, and interactional approach. The cultural approach that poverty is a culture that occurs due to the economic misery that lasted for a long time.

\section{Methodology}

The research location is located in the tourist area of Tulamben and Candidasa Karangasem regency, Bali Province. The study area includes four villages in two sub-districts. The coastal village areas included in this study is the village of Tulamben, and village Purwakerthi. While in Candidasa Region consists of the village of Nyuh Tebel, and the village of Padang Bay. The choice of location is based on the consideration that, in this village developing maritime tourism with various its supporting industries.

The village also has characteristics similar tourist attraction and the community in this village most of livelihood as fishermen or farmers. Karangasem regency election research locations, considering the level of of poverty in the country is the highest in Bali and located in the Eastern Region of Karangasem regency.

Research using purposive sampling method with a sample size 94 respondents. The data analysis using quantitative descriptive analysis (Jennings, 2001: 13).

\section{Results and Discussion}

Karangasem regency has the largest proportion of poor households in Bali Province, which reached $33.66 \%$. This means that every three households there is one poor households. Based on the poverty index of Bali, Karangasem regency also shows the depth and severity of poverty very high poverty. The gap of the 
poor-rich and highly visible and bebeda away, where there are people in the village are very poor through does not had home, on other hand there are people who are very rich. The poverty index are presented in Table 1 below.

Table 1

The depth and Severity Index Poverty in Karangasem regency and Bali Province, Periods 2013-2014

\section{\begin{tabular}{lll}
\hline Wilayah & Depth Index & Severity Index
\end{tabular}}

\begin{tabular}{lllllll}
\hline & 2012 & 2013 & 2014 & 2012 & 2013 & 2014 \\
$\begin{array}{l}\text { Karangasem } \\
\begin{array}{l}\text { Regency } \\
\text { Bali Province }\end{array}\end{array}$ & 1,90 & 0,81 & 1,21 & 0,53 & 0,22 & 0,30 \\
\hline
\end{tabular}

Source : Bali Dalam Angka 2014.

In Table 1. Drawn high poverty gap index in Karangasem signifies still higher average expenditure gap of the poor to the poverty line. Similarly, the poverty severity index that occurred in Karangasem regency higher than the province of Bali. Karangasem regency poverty line per capita per month Rp. 205 860 is much lower of the poverty line Bali Province Rp. 246 598, -

Tulamben region has a population of 32679 people (6,513 families) with balanced composition between men and women. As many as $75 \%$ of the population work as farmers, the rest have a profession as farm laborers, fishermen, entrepreneurs, merchants, and field service. The average community income reached Rp. 1,640,554 through Rp. 2,249,145 per year. Region in particular Tulamben in Tulamben Village and Purwakerti no communities who depend on agriculture but mostly living as fishermen and traders. Residents in this area is quite homogeneous in terms of ethnicity and religion. As a center of tourism in this region is quite diverse types of work compared with other sub-districts, especially the the tourism sector.

Both of these areas have geographical conditions are relatively similar; sloping area from the coast to the hills. Both of these tourism areas have economic characteristics similar to developing the tourism sector, namely sea diving and snorkeling.

\section{Tourism Potency of Tulamben Region}

Tulamben region become the best diving area in Bali because there are no strong currents and location of the dive is not too far from the beach. Moreover, Tulamben have the potential framework of the United States US of merchant ships Liberty that has been covered with various species of corals, anemones, sponges, and live ornamental fish species. Species of fish that live as marine ecosystems Tulamben is angel napoleon, payama angel, angel batman, and a putty knife-genuine monyong spatula. Framework of this vessel are at various depths of $50 \mathrm{~m}$ towing. The water temperature of about $26^{\circ} \mathrm{C}-27^{\circ} \mathrm{C}$ with thermoclines through $24^{\circ} \mathrm{C}$. Visibility sea water in this area reached $15--30 \mathrm{~m}(100 \mathrm{ft}-50)$.

The main purpose of tourists is to see the coral growing on the wreck of the Liberty. The average rating dive for two dives with a duration each in the 
water 40 minutes. These tourists do not stay in Tulamben, but returned to the Denpasar or Badung. The number of tourists per in $i$ Tulamben area approximately 66179 people and in Amed reached 2,853 people. The average length of stay of tourists reached 3-5 days. Additionally in this place tourists also visited Lovina area or returned to the Denpasar. Tourists come with families or couples, thus a lot of who do diving and stay in this area.

Desa Bunutan, a newly developing tourist area with the hotel facilities and dive operators. Tourist who visit this area usually dives in the area Hose and Seraya Island East. This area has a fairly strong current, so tourists who come travelers dominant professional divers and stay at a nearby hotel. There are 25 hotels in the village of Bunutan. Additionally diving, tourists also conducts spiritual travel and honeymoon.

Region of Tulamben has approximately 69 units (2014) spread in Tulamben village, Bunutan Purwakerti. The Price of diving start from Rp 600,000 - Rp 900,000 for a single dive, with dive fun category. The facility is diving equipment and a tour guide.

\section{Tourism Potency of Candidasa Region}

Candidasa area is located in Karangasem regency Candidasa area. There are two potential dive sites visited by tourists, the Gulf and the Gulf of Padang Bai Amuk. Padang Bai is located approximately $60 \mathrm{~km}$ from Denpasar can be reached within 1.5 hours drive from Denpasar. is located in in Padang Bai ferry port Ferry Bali - Lombok. Candidasa area has 9 location of the dive which have varying characteristics. Good dive sites in Padang Bai is the Blue Lagoon, Pura Japan, Bias Tugal, Ferry Channel, and Tanjung Sari. One attraction of diving in Padang Bai is a night dive watch Spanish Dancer that are often encountered in this area. The area is also famous for the photographer (macro photography), because there are many different types of fish start from frog fish, nudibranchs. Teluk Padang Bai excellent dived by all levels of divers, with water visibility average of 1220m, 22--280C temperature, and topography sloping beach.

In the region of Candidasa there are 52 diving services provider, which spread in the village Bugbug and in Padang Bai. The price for a single dive in the category of fun dive around Rp. 400 thousand to 750 thousand, -

\section{Socio Demographic of Respondents}

An overview of the socio-demographic characteristics of the respondents such as age, education, occupation, income, expenditure as described below. Age of respondents between 20 to 60 years. Age of majority is over the age of 60, followed by 40-49 years olde. Such as shown in Table 2 below. 
Table. 2. Socio-Demographic of Respondents

\begin{tabular}{ll}
\hline Characteristic of Respondents & $\begin{array}{l}\text { Total } \\
(\%)\end{array}$ \\
\hline Age (Year) & $38 \%$ \\
$60+$ & $22 \%$ \\
$40-49$ & \\
Education & $34 \%$ \\
Primary School & $29 \%$ \\
Yunior High School & $24.5 \%$ \\
Senior High School & \\
Occupation & $48 \%$ \\
Fisherman and others & $12 \%$ \\
Home Builders & \\
Side Jobs & $52 \%$ \\
Merchant and Diving instructor & $24 \%$ \\
Workers as Transpoter of Diving \\
$\begin{array}{l}\text { Equipments } \\
\text { Drivers }\end{array}$ \\
$\begin{array}{l}\text { Income of Respondents } \\
\text { Les than 300.000 } \\
\text { More than 600.000 }\end{array}$ \\
\hline
\end{tabular}

Based on Table 2, can be drawn that education is negatively correlated with poverty. The more people with low education will lead to increased poverty. The results of this study support the study Gustafsson et al (2006), namely households with many members of the household and heads of of households with low education, the children were at risk of poverty is higher than other communities.

The same is submitted by Affandi (2011), that the households that have household members more than four people with secondary school education level down had chances 1.3 times more likely to be poor than poor households who have the education above junior. This type of work heads of poor households in the region of Candidasa and Tulamben showed a similar pattern. Picture of the kind of work that occupied by. Generally they work as farmers, laborers, traders, and working odd jobs. A side job as a laborer respondents were diving equipment transporter, traders and tour guide and driver

\section{Typology of Poor}

Typology of poor communities in the region of Tulamben and Candidasa can be categorized into three groups:

1. The people who remain with the the old livelihoods, such as fishermen, construction workers, excavation, tenant farmers.

2. People with occasionally works, such as fishermen and local tour guides.

3. People who switched livelihood from the fishermen to be a gardener and souvenir sellers. 


\section{Factors Contributing to Poverty of the Coastal Communities in region of Candidasa and Tulamben}

Poverty in the region of Tulamben and Candidasa is caused by several factors, namely: 1) Natural 2) Culture, 3) Low access to development. Both of these areas are coastal areas directly opposite the mountain. People have a livelihoods as farm laborers and fishermen. Available land dominated by dry land and oceans. It is an irony, in the two of regions, tourism are already developed, however there are still poor communities. This is complicated presence of communities to sell the land alongside the sea to be a hotel or place of business. It is no doubt that Kubu area average is a lava flow during the eruption of Mount Agung. so this area, does not have the structure of the soil to farming. Plants that could live merely rontal and intaran trees. While people raise goats and cows on a small scale to supplement the family income.

A Cultural factors, was habits of Communities doing unproductive activities such as cockfighting or tajen held on Thursdays to Saturdays early morning until late afternoon. Another habit was having a drink, especially drinking palm wine or liquor, especially if there was funeral ceremony.

Low access to tourism development. Due to lack of human resources of poor households, such as lower education and, many of them do not attend school. The average of family burden over three people led to lower revenue and damaged some of the infrastructure. Low of education causes low of society participation in the tourism, only as private security guards, gardeners and laborers who carry the equipment for diving activities. This is in line with the view of Tosun (2000) which has been dividing barriers to participation of society into three parts, namely, operational constraints, structural and cultural barriers.

\section{The Comparison of Tourism Impact on Poor Coastal Communities in Region Tulamben and Candidasa}

A Comparison of impact of tourism on both tourism region can be described from the type of work that occupied before and after the development of tourism. The development of the tourism indirectly affect the change in the people's livelihood in Tulamben and Candidasa. This is in line with the view of Cooper et al, (1993: 116); Murphy and Price (2005: 186); Mill and Morrison (2009: 42), that states the development of tourism in the region will have an impact on changes of the economic structure of society, especially livelihoods of the people.

There are three types of community involvement in the livelihoods: 1) People do not work on any of the the tourism sector, 2) People working in the tourism sector as a side jobs and 3) People working in the tourism sector as the main job.

Communities that worked in tourism sector as a side job, described the community has two types of income namely, from the tourism sector and not from tourism sector who have practiced before developing the tourism. Although there has been society participation in tourism sector approximately $44, \%$, but there were still $56 \%$ of people who have not participated in tourism sector 
This phenomenon is due to a lot of things such as presence of society's understanding of the role of tourism and the desire to benefit from tourism. Because poor communities is also due to cultural factors, such as lazy and spend money have been obtained for negative things such as gambling. Community participation in the Candidasa area approximately $50 \%$ higher than the area of Tulamben is about $37 \%$.

This is in line with the view of Asley, that poverty can be resolved not only because the role of government and tourism actors but also the need of community in participation and empowerment of communities where the tourism is developed (Asley, 2006; Asley and Haysom, 2006; Asley and Goodwin, 2007). An overview of community involvement are presented in Table 3.

Table 3.

Community Involvement Category Before and After Development of Tourism in the region of Tulamben and Candidasa

\begin{tabular}{|c|c|c|c|c|c|}
\hline \multirow[b]{2}{*}{ No } & \multirow{2}{*}{$\begin{array}{l}\text { A category of } \\
\text { Livelihoods } \\
\text { communities }\end{array}$} & \multirow{2}{*}{\multicolumn{2}{|c|}{$\begin{array}{l}\text { Before Tourism } \\
\text { Development }\end{array}$}} & \multicolumn{2}{|c|}{$\begin{array}{l}\text { After } \\
\text { Touris } \\
\mathrm{m}\end{array}$} \\
\hline & & & & & \\
\hline \multirow[b]{2}{*}{1} & \multirow[b]{2}{*}{$\begin{array}{l}\text { Does Not Work On } \\
\text { Tourism Sector }\end{array}$} & Tulamben & Candidasa & Tulamb & Candida \\
\hline & & 93.3 & 90.0 & 63.3 & 50.0 \\
\hline 2 & $\begin{array}{lll}\text { Working } & \text { On } & \text { Tourism } \\
\text { Sector But } & \text { Only } & \text { For Side } \\
\text { job } & & \\
\end{array}$ & 6.7 & 6.7 & 30.0 & 33.3 \\
\hline 3 & $\begin{array}{l}\text { Work on Tourism Sector as } \\
\text { Major Occupation }\end{array}$ & 0.0 & 3.3 & 6.7 & 16.7 \\
\hline & Jumlah & 100 & 100 & 100 & 100 \\
\hline
\end{tabular}

\section{Conclusions}

Based on the research objectives that have been discussed in previous chapters. Can be summarized as follows. Tipelogi poverty in Karangasem was: first, the community have same livelihood with before the tourism developed. Secondly, people have livelihood side jobs . Third, the community switched worked in tourism sector.

Characteristics of poverty in region of Tulamben and Candidasa caused many factors namely: by natural factors, low education levels, lack of infrastructure, and the mental attitude and culture owned. The development of tourism has an impact on changing the livelihoods of the people which leads to a heterogeneous typology.

In general, poor communities respond positively to the development of the tourism as an activity that gives hope to improve the welfare of society. But there are still poor communities who do not take part in the tourism sector. This is due to internal and external obstacles in participating. Barriers to the participation of society it is divided into three parts, namely operational constraints, structural 
barriers, and cultural barriers. The slowness the public in participating in tourism due to the mental attitude the community who are less willing to break out of the cycle of poverty and lack of understanding of the role of tourism as a business that can increase the income, so the motivation to worked productively is remains low.

\section{Suggestions}

Suggestions can be submitted in reducing poverty using of tourism management approach namely:

1. The Community is expected to utilize the growing tourism industry in Bali as an opportunity to boost the economy, educational and competence in the field of tourism.

2. The government and private sector are expected to provide assistance tourist infrastructure improvements to reduce barriers to accessibility, assistance specific to the skills. Universities are also expected to contribute in motivating to the community to raise awareness in participating in tourism sector.

3. The future research need to be done on a wider area, thereby generalizing the results more widely too.

\section{REFERENCES}

Asley,C., Roe,D and Goodwin, H. (2000). Pro Proo Tourism: putting poverty at the heart of the tourism agenda. London, Overseas Development Institute.

Ashley, C., and Roe, D. (2002). Making Tourism Work for the Poor: Strategies and Challenges in Southern Africa. Development Southerm Africa Vol. 19 No.1. pg 61-82. Carfax Publishing, Taylor and Francis Group.

Ashley, Caroline. (2002). Methodology for Pro-Poor Tourism Case Studies. Working Paper. Overseas Development Institute.

Ashley, C., and Haysom, G. (2006). "From philanthropy to a different way of doing business: strategies and challenges in integrating pro poor approaches into tourism business". Internasional Journal of Development Southerm Africa Vol. 23 No.22. pg 265-280. Rotledge, Taylor and Francis Group.

Ashley, Caroline. (2006). How Can Government Boost the Local Economic Impact of Tourism, option and too. For SNV East and Southern Africa. Overseas Development Institute

Asley C and Goodwin, H. (2007)." Pro Poor Tourism": What's gone right and what's gon wrong?. London Overseas Development Institute.

Badan Pusat Statistik Provinsi Bali. (2014) Bali Dalam Angka. 2014. Denpasar: BPS Bali. 
Cooper, Chris; Fletcher, Jhon, Gilbert, David and Wanhill, Stephen. (1993). Tourism Principles \& Practice. UK: PITMAN

Damanik, J., Kusworo, H. A., dan Raharja, D.T. (2005) Penanggulangan Kemiskinan Melalui Pariwisata. Jakarta: Pusat Studi Pariwisata UGM dan Kementrian Bidang Kesejahteraan Rakyat Republik Indonesia.

Darma Putra, I Nyoman dan Pitana, I Gde. (2010). Pariwisata Pro-Rakyat. Jakarta: Kementerian Kebudayaan dan Pariwisata Republik Indonesia

Jennings, Gayle. (2001). Tourism Research, Australia: Wiley.

Leon, Y. M. (2007). "The Impact of Tourism on Rural Livelihoods in the Dominican Republic' Costal Areas". Journal of Development Studies. Vol.43. No.2, 340-359, ISSN 0022-0388. February 2007. New York. Rotledge, Taylor and Francis.

Madiun. I Nyoman. (2010). Nusa Dua Model Pengembangan Kawasan Wisata Moderen, Denpasar: Udayana University Press.

Mill, Robert Christie and Morrison, Alastair M. (2009). The Tourism System. USA: Kendall Hunt.

Mograbi, J and Rogerson, C. M. (2007). "Maximising the Lokal Pro-Poor Impacts of Dive Tourism: Sodwana Bay, South Africa". Urban Forum (2007) 18:85-104. Publised online 26 July 2007. Springer Link. Media B.V.

Murphy, Peter E and Price Garry G. (2005). Tourism and Sustainable Development. In Global Tourism. Ed. Theobald, William F, USA: Elsevier.

Richins, Harold and Hull, John. (2014). An Evaluation of Pro-Poor Tourism Case Interventions in Communities in Southeast Asia: Developing an Adapted Typology. Processing Tourism in Indonesia. International Conference on Tourism in Indonesia, Bali, 24-27 March 2014, pp. 292-295

Suardana, Wayan. (2004). "Strateggi Pengembangan Pesisir Pantai Tulamben Sebagai Kawasan Wisata Alam di Kabupaten Karangasem”. Thesis. Denpasar: Program Pasca Sarjana Universitas Udayana.

Sudiarta, I Nyoman, Suardana, I Wayan dan Ni Ketut Arismayanti. (2011). Pengembangan Konsep Pariwisata Yang Pedulu Pada Kemiskinan (Pro Poor Tourism) Sebagai Strategi Dalam Mengurangi Kemiskinan, Laporan Penelitian, Denpasar, Fakultas Pariwisata Universitas Udayana.

Subagja. (2010). "DPRD Sesalkan Wisata Kemiskinan di Jakarta". Diakses dari Detik News. Minggu 24 Januari 2010. http//m.detik.com. 
Hill, Trevor., Nel, Etiienne and Trotter, Dayle. 2005. Small-scale, nature-based as a poor-poor development intervention: Two examples in Kwazulu-Natal, South Africa. Singapore Journal of Tropical Geography, Vol. 27, Issue 2. Pp. 163-175.

United Nations World Tourism Organization. (2015). Global Forecast and Profiles of Market Segment. 